\title{
Purification, Characterization, and Potential of Saline Waste Water Remediation of a Polyextremophilic $\alpha$-Amylase from an Obligate Halophilic Aspergillus gracilis
}

\author{
Imran Ali, ${ }^{1,2}$ Ali Akbar, ${ }^{3}$ Benjawan Yanwisetpakdee, ${ }^{1}$ Sehanat Prasongsuk, ${ }^{1}$ \\ Pongtharin Lotrakul, ${ }^{1}$ and Hunsa Punnapayak ${ }^{1}$ \\ ${ }^{1}$ Plant Biomass Utilization Research Unit, Department of Botany, Faculty of Science, Chulalongkorn University, \\ Bangkok 10330, Thailand \\ ${ }^{2}$ Institute of Biochemistry, University of Balochistan, Quetta 87300, Pakistan \\ ${ }^{3}$ Food Engineering and Bioprocess Technology, School of Environment, Resources and Development, \\ Asian Institute of Technology, Klong Luang, Pathumthani 12120, Thailand
}

Correspondence should be addressed to Imran Ali; imranalisheik@gmail.com

Received 17 February 2014; Revised 24 April 2014; Accepted 26 April 2014; Published 14 May 2014

Academic Editor: Paul M. Tulkens

Copyright (C) 2014 Imran Ali et al. This is an open access article distributed under the Creative Commons Attribution License, which permits unrestricted use, distribution, and reproduction in any medium, provided the original work is properly cited.

\begin{abstract}
An obligate halophilic Aspergillus gracilis which was isolated from a hypersaline man-made saltern from Thailand was screened for its potential of producing extracellular $\alpha$-amylase in the previous studies. In this study the $\alpha$-amylase was extracted and purified by the help of column chromatography using Sephadex G-100 column. Presence of amylase was verified by SDS-PAGE analysis, showing a single band of approximately $35 \mathrm{kDa}$. The specific activity of the enzyme was found to be $131.02 \mathrm{U} / \mathrm{mg}$. The LineweaverBurk plot showed the $V_{\max }$ and $K_{m}$ values of $8.36 \mathrm{U} / \mathrm{mg}$ and $6.33 \mathrm{mg} / \mathrm{mL}$, respectively. The enzyme was found to have the best activity at $5 \mathrm{pH}, 60^{\circ} \mathrm{C}$, and $30 \%$ of $\mathrm{NaCl}$ concentration, showing its polyextremophilic nature. The use of various additives did not show much variation in the activity of enzyme, showing its resilience against inhibitors. The enzyme, when tested for its use for synthetic waste water remediation by comparing its activity with commercial amylase in different salt concentrations showed that the $\alpha$-amylase from A. gracilis was having better performance at increasing salt concentrations than the commercial one. This shows its potential to be applied in saline waste water and other low water activity effluents for bioremediation.
\end{abstract}

\section{Introduction}

Extremophiles are able to reproduce and grow at extremes of $\mathrm{pH}$, temperature, salinity, and so forth. Halophiles are those extremophiles which are able to withstand extremes of salinity [1]. Halophilic fungi can be defined as those which are frequently found in hypersaline habitats at $\mathrm{NaCl}$ concentrations above $1.7 \mathrm{M}$ and they are able to grow in vitro at $3 \mathrm{M}$ salt concentration $[2,3]$. Halophilic fungi which are unable to grow without the presence of required $\mathrm{NaCl}$ concentrations are called as obligate halophilic fungi [1].

Extremophiles have long been studies for their metabolites which are capable of working at extreme available conditions [4]. Currently there are several fermentation processes in which halophiles and their metabolites are used [5]. There are reports of using halophilic metabolites as food additives, biosurfactants, biorhodopsins, and biocompatible solutes $[3,6]$. The ability of extremophiles to produce hydrolytic extremozymes has been much studied for its possible applications in industries $[7,8]$. Mostly halophilic hydrolases such as amylases, cellulases, lipases, xylanases, and proteases have been reported from halophilic bacteria [9]. Except for few preliminary studies there have not been many investigations on the extremozymes from halophilic fungi, particularly obligate halophilic fungi $[3,10]$.

Amylases are potent industrial enzymes used in textile, laundry, pharmaceutical, and food industries [11, 12]. The $\alpha$ amylase (EC 3.2.1.1) is an important class of amylases which constitutes approximately $25 \%$ of its share in total enzyme market [13]. 
Aspergillus gracilis TISTR 3638 was isolated from a man-made solar saltern, present in Phetchaburi province of Thailand. The isolate was morphologically and molecularly identified. Characterization studies of fungus revealed the obligate halophilic nature of the fungi [1]. The strain was then deposited to the culture collection center of Thailand Institute of Scientific and Technological Research (TISTR). The fungus was found to have extracellular amylase (see Supplementary Figure 1 in the Supplementary Material available online at http://dx.doi.org/10.1155/2014/106937), when its biotechnological potentials were investigated [3].

It was assumed from previous studies on other halophilic microbes that the amylase from A. gracilis may have polyextremophilic nature which can make it applicable in many industrial processes. So, in quest of that, the purification and characterization of $\alpha$-amylase were performed. The purified amylase was tested for its potential in the use of waste water management. To the best of our knowledge this is the first report of use of amylase for waste water remediation from any halophilic fungi, especially from obligate halophilic fungi.

\section{Materials and Methods}

2.1. Growth Conditions for Enzyme Production. Fresh culture of Aspergillus gracilis was grown on the potato dextrose agar (PDA) supplemented with $1 \%(\mathrm{w} / \mathrm{v})$ soluble starch and $10 \%$ $(\mathrm{w} / \mathrm{v})$ of $\mathrm{NaCl}$ concentration. Five $\mathrm{mm}$ of two discs obtained by cock borer was inoculated in $100 \mathrm{~mL}$ of production medium in $150 \mathrm{~mL}$ Erlenmeyer flask. A. gracilis was grown in the production medium at room temperature $\left(25 \pm 2^{\circ} \mathrm{C}\right)$ at $150 \mathrm{rpm}$ for 14 days. The medium for amylase production was made by following Hernández et al. [14] with required modifications. A. gracilis was found growing best at $10 \%$ salt concentration in our previous finding [1], so the medium was supplemented with $10 \% \mathrm{NaCl}(\mathrm{w} / \mathrm{v})$. The medium was composed of $8.0 \mathrm{~g} / \mathrm{L} \mathrm{CaCO}_{3}, 0.15 \mathrm{~g} / \mathrm{L} \mathrm{FeSO} \cdot 7 \mathrm{H}_{2} \mathrm{O}, 3.5 \mathrm{~g} / \mathrm{L}$ $\mathrm{KH}_{2} \mathrm{PO}_{4}, 0.10 \mathrm{~g} / \mathrm{L} \mathrm{MgSO}_{4} \cdot 7 \mathrm{H}_{2} \mathrm{O}, 3.0 \mathrm{~g} / \mathrm{L}$ mycological peptone, $100 \mathrm{~g} / \mathrm{L} \mathrm{NaCl}, 6.6 \mathrm{~g} / \mathrm{L}\left(\mathrm{NH}_{4}\right)_{2} \mathrm{SO}_{4}$, and $10 \mathrm{~g} / \mathrm{L}$ soluble starch.

2.2. Amylase Purification. The methodologies adopted by previous researchers $[15,16]$ for the purification of amylase were followed. Supernatant from the growth media was obtained by centrifuging the broth at $13,000 \times \mathrm{g}$ at $4^{\circ} \mathrm{C}$ for $10 \mathrm{~min}$. The enzyme was precipitated by the addition of solid ammonium sulfate bringing the filtrate to $90 \%$ saturation. The mixture was incubated overnight at $4^{\circ} \mathrm{C}$. The precipitate obtained was then centrifuged for $30 \mathrm{~min}$ at $12,000 \times \mathrm{g}$ and dissolved in $100 \mathrm{mM}$ Tris-HCl buffer ( $\mathrm{pH} \mathrm{6)}$. The enzyme was then dialyzed for $48 \mathrm{~h}$ using same buffer. The precipitate obtained was then applied for gel filtration by Sephadex G100 column $(2.6 \mathrm{~cm}-150 \mathrm{~cm})$, which was preequilibrated with 25 mM Tris- $\mathrm{HCl}$ buffer ( $\mathrm{pH} 6$, containing 0.5\% Triton X-100). Enzyme fractions of $5 \mathrm{~mL}$ were eluted by using same buffer at a flow rate of $30 \mathrm{~mL} / \mathrm{h}$.

The purity and molecular weight of the purified amylase were determined by sodium dodecyl sulphate polyacrylamide gel electrophoresis (SDS-PAGE). The methodology explained by Hmidet et al. [16] was followed by using 5\% stacking and $15 \%$ separating gels. The purified enzyme was mixed at 1:5 ratio $(\mathrm{v} / \mathrm{v})$ with distilled water having $10 \mathrm{mM}$ Tris- $\mathrm{HCl}$ (pH 6), SDS 2.5\%, b-mercaptoethanol 5\%, glycerol $10 \%$, and bromophenol blue $0.002 \%$. Before electrophoresis the sample was heated for $5 \mathrm{~min}$ at $100^{\circ} \mathrm{C}$. Gels were stained with $0.25 \%$ Coomassie Brilliant Blue R250 in 45\% ethanol$10 \%$ acetic acid and destained with $5 \%$ ethanol-7.5\% acetic acid. Molecular marker kit (Bio-Rad) was used for the reference of molecular weights of protein.

2.3. Amylase Assay. Activity of amylase was determined by dinitrosalicylic acid (DNS) method of reducing sugar explained by Miller [17]. $0.1 \mathrm{~mL}$ amylase was added with $0.5 \mathrm{~mL}$ of $0.1 \mathrm{M}$ acetate buffer having $1 \%(\mathrm{w} / \mathrm{v})$ soluble starch. The reaction mixture was incubated for $10 \mathrm{~min}$ at $40^{\circ} \mathrm{C}$. The reaction was stopped by $3 \mathrm{~mL}$ of 3,5-dinitrosalicylic acid and the mixture was heated at $100^{\circ} \mathrm{C}$ for $5 \mathrm{~min}$ in boiling water bath. $10 \mathrm{~mL}$ of water was added and the absorbance was determined at $540 \mathrm{~nm}$. One unit of enzyme activity (U) was defined as the amount of enzyme that produced $1 \mu \mathrm{mol}$ of glucose in $1 \mathrm{~min}$.

2.4. Protein Estimation. The amount of protein was determined by following methodology adopted by Lowry et al. [18]. Bovine serum albumin (BSA) was used as the standard.

2.5. Characterization of Amylase. The amylase was characterized in various $\mathrm{pH}$, temperatures, and $\mathrm{NaCl}$ concentrations. The results were explained in percentage relative activity.

The $\mathrm{pH}$ range of 3-8 at constant temperature was provided for the determination of effect of $\mathrm{pH}$ on enzyme activity. For acidic range of $\mathrm{pH} 0.1 \mathrm{M}$ acetate buffer was used, while for neutral and alkaline ranges of $\mathrm{pH} 0.1 \mathrm{M}$ phosphate buffer was utilized. The sample mixture was incubated at $30-90^{\circ} \mathrm{C}$ at constant $\mathrm{pH}$ for the determination of effect of temperatures on enzyme activity. The effect of salinity on the enzyme activity was determined by supplementing the sample mixture at $0-40 \% \mathrm{NaCl}$ concentration $(\mathrm{w} / \mathrm{v})$ at constant $\mathrm{pH}$ and temperature.

The effects of various activators and deactivators on the enzyme activity were determined by adding $2 \mathrm{mM} \mathrm{b}$ mercaptoethanol, $\mathrm{FeCl}_{2}$, ethylene diamine tetra-acetic acid (EDTA), $\mathrm{CaCl}_{2}, \mathrm{BaCl}_{2}, \mathrm{MgCl}_{2}, \mathrm{HgCl}_{2}$, and $\mathrm{ZnCl}_{2}$. The effect of additives was compared with the control having no additive. The results are explained in percentage relative activity.

2.6. Determination of Kinetic Parameters. The kinetic parameters were estimated by incubating the enzyme at various concentrations of soluble starch. The optimum conditions found in the characterization studies were used in kinetic studies. Lineweaver-Burk plotwas used for finding the $V_{\max }$ and $K_{m}$ values.

2.7. Waste Water Treatment. The potential of amylase from A. gracilis was determined for waste water remediation. The performance was checked by comparing the efficiency with commercial grade amylase. Synthetic waste water 


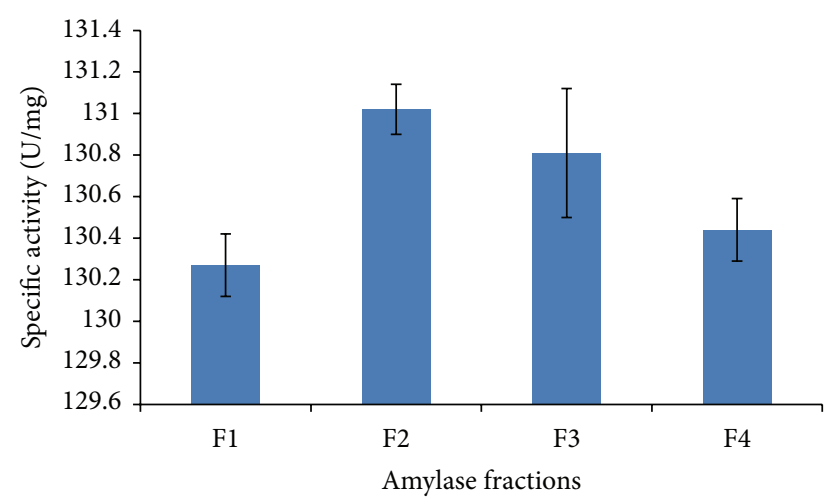

Figure 1: Fractions of $\alpha$-amylase obtained from $A$. gracilis TISTR 3638 , produced at flow rate of $30 \mathrm{~mL} / \mathrm{h}$ by column chromatography.

was made following the composition used by Kapdan and Erten [19] with few modifications. The medium was composed of soluble starch $10 \mathrm{~g} / \mathrm{L}, \mathrm{NH}_{4} \mathrm{Cl} 1 \mathrm{~g} / \mathrm{L}$, $\mathrm{KH}_{2} \mathrm{PO}_{4} 0.3 \mathrm{~g} / \mathrm{L}, \mathrm{MgCl} \cdot 6 \mathrm{H}_{2} \mathrm{O} 2 \mathrm{~g} / \mathrm{L}, \mathrm{CaCl}_{2} \cdot 2 \mathrm{H}_{2} \mathrm{O} 0.2 \mathrm{~g} / \mathrm{L}$, $\mathrm{C}_{2} \mathrm{H}_{3} \mathrm{NaO}_{2} \cdot 3 \mathrm{H}_{2} \mathrm{O} 1 \mathrm{~g} / \mathrm{L}$, and trace element solution $1 \mathrm{~mL} / \mathrm{L}$. The trace element solution was made by $\mathrm{MgSO}_{4} \cdot 7 \mathrm{H}_{2} \mathrm{O} 3 \mathrm{~g} / \mathrm{L}$, $\mathrm{MnSO}_{4} \cdot 2 \mathrm{H}_{2} \mathrm{O} 0.5 \mathrm{~g} / \mathrm{L}, \mathrm{FeSO}_{4} \cdot 7 \mathrm{H}_{2} \mathrm{O} 0.1 \mathrm{~g} / \mathrm{L}, \mathrm{CaCl}_{2} \cdot 2 \mathrm{H}_{2} \mathrm{O}$ $0.1 \mathrm{~g} / \mathrm{L}, \quad \mathrm{ZnSO}_{4} \cdot 7 \mathrm{H}_{2} \mathrm{O} \quad 0.180 \mathrm{~g} / \mathrm{L}, \quad \mathrm{CuSO}_{4} \cdot 5 \mathrm{H}_{2} \mathrm{O} \quad 0.01 \mathrm{~g} / \mathrm{L}$, $\mathrm{H}_{3} \mathrm{BO}_{3} 0.01 \mathrm{~g} / \mathrm{L}, \mathrm{Na}_{2} \mathrm{MoO}_{4} \cdot 2 \mathrm{H}_{2} \mathrm{O} 0.01 \mathrm{~g} / \mathrm{L}$, and $\mathrm{NiCl}_{2} \cdot 6 \mathrm{H}_{2} \mathrm{O}$ $0.25 \mathrm{~g} / \mathrm{L}$.

The sample mixtures were made by the addition of $10 \%$ of amylase from A. gracilis and commercial amylase. The sample mixtures were supplemented with $0-25 \%$ of $\mathrm{NaCl}$ concentrations and incubated for 1 hour at constant $\mathrm{pH}$ and temperature. Blank was used as negative control having no enzyme. The change in dissolved oxygen (DO) was monitored by DO meter (DO-5519 Lutron, Taiwan). The results are explained in percentage relative efficiency, where the increase in DO by the amylase from A. gracilis was considered as control and its DO values were taken as $100 \%$.

2.8. Statistical Analysis. Experiments were performed with required controls. Data is presented as mean \pm standard deviation (SD) of triplicate readings. A value of $P<0.05$ was considered significant.

\section{Results}

3.1. Purification of Amylase. The purity and molecular weight of $\alpha$-amylase was determined from the F2 fraction showing highest amylase activity (Figure 1). The purified amylase was found to have a single band at approximately $35 \mathrm{kDa}$ (Figure 2). The specific activity of the purified amylase from A. gracilis was found as $131.02 \mathrm{U} / \mathrm{mg}$. Approximately 6 folds of purification were found by purification with $47 \%$ yield (Table 1).

3.2. Characterization of Amylase. The effect of different $\mathrm{pH}$ ranges on the enzyme activity showed that amylase was having high activity at acidic to neutral $\mathrm{pH}$ ranges (Figure 3 ).

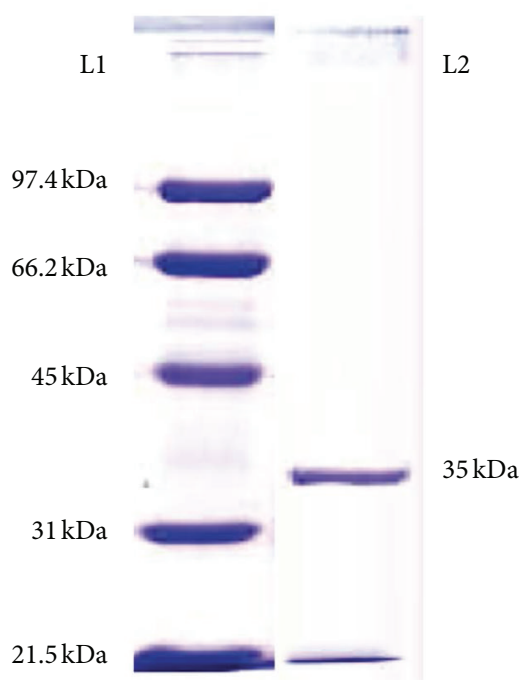

Figure 2: SDS-PAGE analysis of the purified $\alpha$-amylase from $A$. gracilis TISTR 3638. L1 represents lane 1, which is the molecular mass ladder. L2 represents lane 2, which is the purified $\alpha$-amylase lane, showing single band at approximately $35 \mathrm{kDa}$.

Increase in $\mathrm{pH}$ was found to decrease the enzyme activity. The optimum enzyme activity was found at $5 \mathrm{pH}$.

The effect of different temperatures on enzyme activity showed that amylase was able to work better from moderate to high temperatures (Figure 4). Steady increase in enzyme activity was observed from 30 to $60^{\circ} \mathrm{C}$. A sharp decrease in enzyme activity was found at temperatures over $60^{\circ} \mathrm{C}$.

The effect of various salinity concentrations on amylase activity revealed the halophilic nature of the enzyme (Figure 5). A gradual increase in enzyme activity was observed at increasing $\mathrm{NaCl}$ concentrations. The optimum enzyme activity was observed at $30 \%$ salt concentration. The enzyme was able to show over $30 \%$ more efficiency at very high salt concentration of $30 \%$ as compared to $0 \%$ salt concentration. The decrease in enzyme activity was observed from salinity above $30 \%$ of $\mathrm{NaCl}$ concentration but still more than $90 \%$ of enzyme activity was retained at $40 \%$ of $\mathrm{NaCl}$ concentration which is above the saturation point of saline solutions.

The effect of various additives on the enzyme exhibited its resilience to enzyme inhibition (Table 2). None of the inhibitors was able to decrease lower than $90 \%$ of enzyme activity. However the activators were also not able to influence the enzyme activity as well. Over all $\mathrm{BaCl}_{2}, \mathrm{MgCl}_{2}, \mathrm{HgCl}_{2}$, and $\mathrm{CaCl}_{2}$ were able to increase the enzyme activity, while $\mathrm{FeCl}_{2}$, b-mercaptoethanol, $\mathrm{ZnCl}_{2}$, and EDTA were able to decrease the enzyme activity.

3.3. Enzyme Kinetics. The enzyme kinetics was determined by Lineweaver-Burk plot (Figure 6). The $V_{\max }$ and $K_{m}$ values of amylase from A. gracilis were found to be $8.36 \mathrm{U} / \mathrm{mg}$ and $6.33 \mathrm{mg} / \mathrm{mL}$, respectively. 
TABLE 1: Purification properties of $\alpha$-amylase from A. gracilis TISTR 3638.

\begin{tabular}{lccc}
\hline Properties & Cell free supernatant & $\left(\mathrm{NH}_{4}\right)_{2} \mathrm{SO}_{4}$ precipitation & Gel purification \\
\hline Total protein $(\mathrm{mg})$ & $215.54 \pm 1.21$ & $634.33 \pm 0.85$ & $183.51 \pm 0.82$ \\
Total activity (U) & $45718.27 \pm 0.93$ & $36207.55 \pm 0.07$ & $24043.48 \pm 1.15$ \\
Specific activity (U/mg) & $21.19 \pm 0.47$ & $57.08 \pm 1.02$ & $131.02 \pm 0.43$ \\
Yield (\%) & 100 & 73 & 47 \\
Purification fold & 1.0 & 2.69 & 6.18 \\
\hline
\end{tabular}

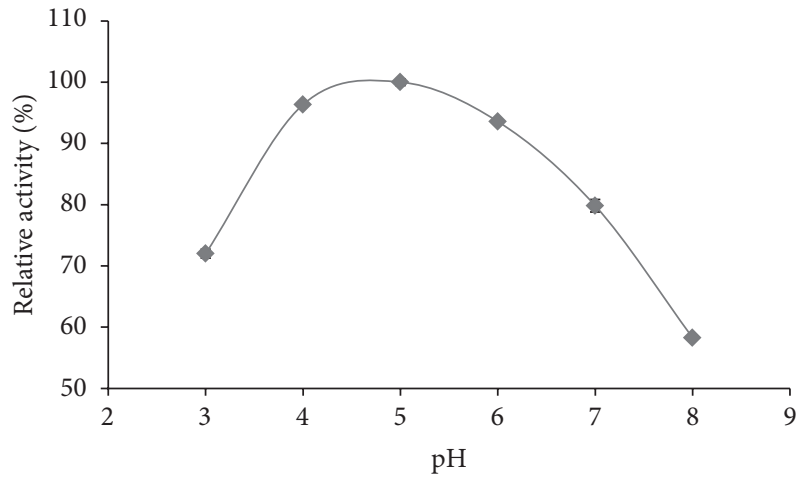

FIGURE 3: Effect of $\mathrm{pH}$ on the purified $\alpha$-amylase activity from A. gracilis TISTR 3638 at constant temperature. The results are expressed in percentage relative activity.

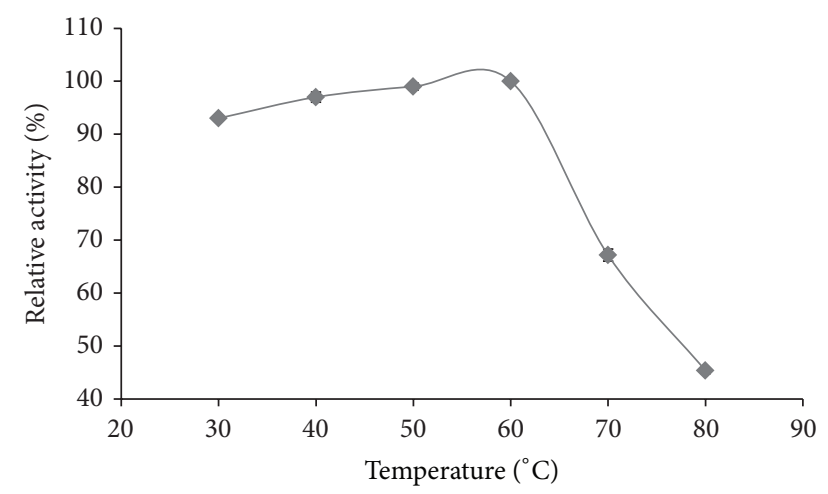

FIGURE 4: Effect of temperature on the purified $\alpha$-amylase activity from A. gracilis TISTR 3638 at constant $\mathrm{pH}$. The results are expressed in percentage relative activity.

3.4. Waste Water Treatment. Remediation of synthetic waste water was monitored by increase in the DO. In comparison to the performance of amylase from A. gracilis (control) the efficiency of commercial amylase was found to be decreased by the increase in $\mathrm{NaCl}$ concentrations (Figure 7).

\section{Discussion}

There is a constant search by researchers for finding suitable fungal strains for the amylase production [20]. Mesophilic fungi have been mostly reported for the production of amylases [21]. The amylase production has been dominated by Aspergillus and Penicillium genus [22]. In industrial
TABLE 2: Effect of various additives on the $\alpha$-amylase from A. gracilis TISTR 3638.

\begin{tabular}{lc}
\hline Additives $(2 \mathrm{mM})$ & Relative activity (\%) \\
\hline None & 100 \\
$\mathrm{BaCl}_{2}$ & $101.05 \pm 1.5$ \\
$\mathrm{CaCl}_{2}$ & $101.47 \pm 0.1$ \\
$\mathrm{FeCl}_{2}$ & $89.42 \pm 1.0$ \\
$\mathrm{HgCl}_{2}$ & $100.24 \pm 1.5$ \\
$\mathrm{MgCl}_{2}$ & $100.33 \pm 0.3$ \\
$\mathrm{ZnCl}$ & $90.38 \pm 1.5$ \\
b-Mercaptoethanol & $98.01 \pm 0.5$ \\
EDTA & $90.41 \pm 1.0$ \\
\hline
\end{tabular}

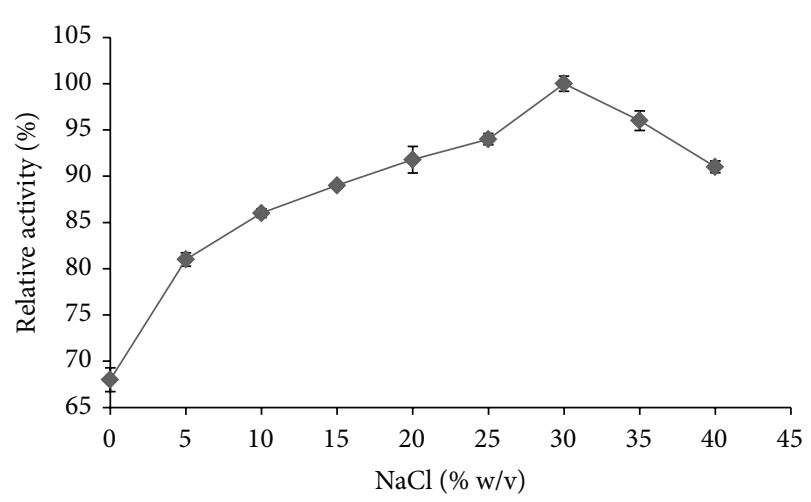

FIGURE 5: Effect of $\mathrm{NaCl}$ concentrations (\%w/v) on the purified $\alpha$ amylase activity from A. gracilis TISTR 3638 at constant $\mathrm{pH}$ and temperature. The results are expressed in percentage relative activity.

operations the amylases from fungi are preferred due to their acceptable characteristics such as in food and pharmaceutical industries [23]. The species from Aspergillus genus, such as Aspergillus oryzae and Aspergillus niger are commonly used for the production of amylases in industries [24]. Fungi were not designated as halophilic microorganisms before year 2000 [2]. Therefore there are not many reports of amylase from halophilic fungi. To the best of our knowledge this is the first attempt of using amylase for remediation of waste water from halophilic fungi, especially obligate halophilic fungi.

A single band obtained in purification step suggests that there is no further need of any purification of this enzyme. The molecular masses from halophilic fungi have been mostly reported in the range of $50-75 \mathrm{kDa}$ [9]. The $\alpha$-amylase obtained from A. gracilis TISTR 3638 was found to be smaller in this study with an approximate mass of $35 \mathrm{kDa}$ (Figure 2). 


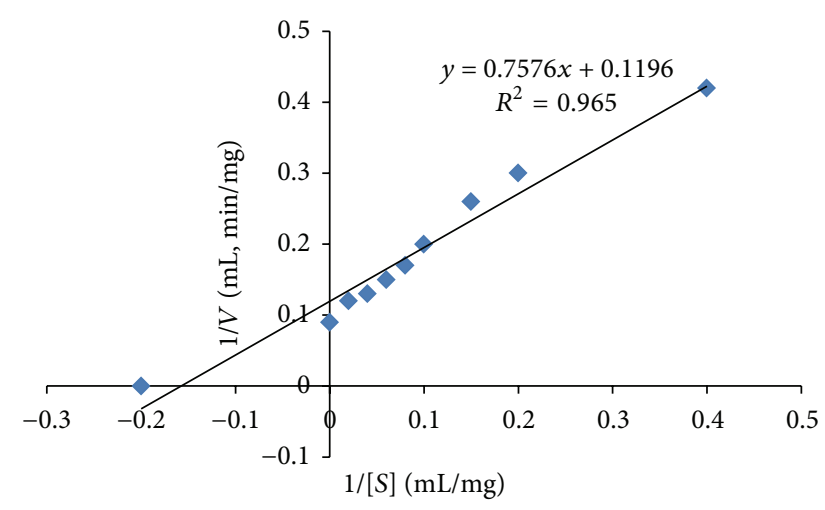

Figure 6: Lineweaver-Burk plot for the determination of $V_{\max }$ and $K_{m}$ values of the purified $\alpha$-amylase from $A$. gracilis TISTR 3638, at optimum conditions, in the presence of different concentrations of soluble starch.

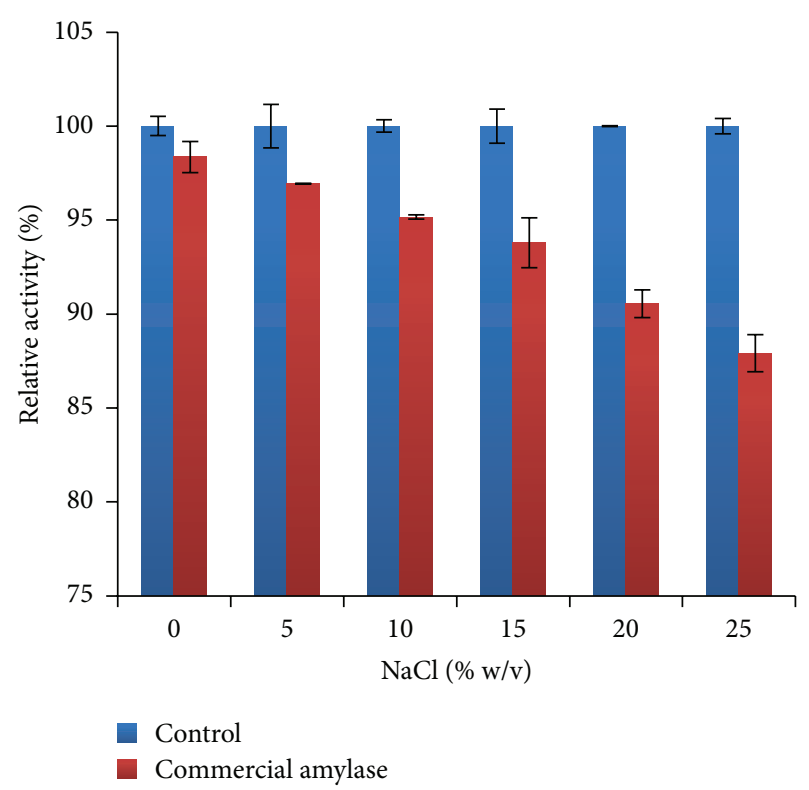

FIGURE 7: Comparative analysis of waste water remediation between control ( $\alpha$-amylase from E A. gracilis TISTR 3638) and commercial grade amylase at different salinity levels.

The specific activity of amylase in this study was found in the moderate ranges as compared to previous reports [15]. The $K_{m}$ value of the amylases has been mostly reported from 0.35 to $11.66 \mathrm{mg} / \mathrm{mL}$ [25], which corresponds to our report.

The optimum $\mathrm{pH}$ value of amylase from this study is found in the acidic range, which is slightly different to the growth characterization results of A. gracilis 3638, as it was found growing best at $7 \mathrm{pH}$ [1]. Similarly, it has also been found different to the habitat conditions of hypersaline environment, as mostly the hypersaline environments are found to have $\mathrm{pH}$ values from neutral to slightly alkaline [5]. The optimum $\mathrm{pH}$ value of 5 has been considered as acidophilic by researchers [26, 27]. Acidophilic amylases can work better in acidic waste water [28] and they can work better at extremes of acidic $\mathrm{pH}$ in the stomach [27].
Most of the enzymes are reported being unable to work at temperatures more than $50-60^{\circ} \mathrm{C}$ [29]. The optimum activity of amylase in this study has been found at $60^{\circ} \mathrm{C}$, which is near to be the standard thermophilic category of amylases, which is $70-80^{\circ} \mathrm{C}[30,31]$. Thermophilic amylases are mostly used in the starch and baking industries [29].

Obligate halophilic fungi are unable to survive in the absence of required salt concentration. The minimal required salt concentration for A. gracilis TISTR 3638 has been found at $5 \% \mathrm{NaCl}(\mathrm{w} / \mathrm{v})$ [1]. This characteristic provided a hypothesis for this study that amylase must be requiring salt concentration for better activity. Salt concentration of $10 \%(\mathrm{w} / \mathrm{v})$ has been mostly found best for the production of amylases from halophilic microorganisms [13, 32]. Consider that $10 \%$ of salt was supplemented in the production media of amylases, which signifies the halophilic characteristic of enzyme production. Amongst halophiles, the Archaea and bacteria are considered most extreme halophilic microbes and their metabolites are also considered extremely halophilic. Amylase in this study, being able to perform best at $30 \%$ of $\mathrm{NaCl}$ concentration, has been found more extremely halophilic as compared to many reports on amylases from halophilic archaea and bacteria $[8,13,33]$. The halophilic extremity of amylases in this study adds the novelty to this enzyme. This finding also provides an insight into the fact that metabolites from halophilic fungi have been much neglected in biotechnology, although they have the ability to work better at low water activity or high salt concentrations' processes in industries.

The halophilic amylases from microbial sources have often been reported to work better at more than one extremity of available conditions, thus showing the polyextremophilic behavior $[8,13]$. Amylase in this study has been found being acidophilic, thermophilic, and halophilic: making it fall into the category of polyextremophilic enzymes. However, the characteristic of amylase from A. gracilis TISTR 3638 has been found different from the typical behavior of extremozymes obtained from halophilic microorganisms, as most of them are found to be haloalkaliphilic [9]. Enzymes having ability to work at extremes of available conditions are found more potent for application in industrial processes [34]. The polyextremophilic behavior shown by amylase in this study makes it available to work at low $\mathrm{pH}$, high temperatures, low water activity, and high salt concentration processes in industries.

Climate changes and continuously changing world are requiring new demands from biotechnology. There are several places in the world where people have to use underground untreated water for domestic purposes, which decreases the performance of many detergents [35-37]. The use of amylase from this study as an additive in the laundry detergents can solve this problem and can also reduce the consumption of water. Depletion of fossil fuels requires the use of biofuels as alternatives. Halophilic enzymes are also being reported to work better than normal enzymes in the biofuel production processes [38].

Similarly, the increased demands of food, clothes, and other utilities have increased the demand of production from industries, which is ultimately causing increase in waste 
water production [39]. Addition of any pollutant in the waste water decreases the DO in the water. Several food, pharmaceutical, and textile industry effluents are rich in starch, fiber, and other organic pollutants which are very harmful for environment [40]. In addition to that, there are various industries producing saline and acidic waste water such as fertilizer industries, fish sauce production units, and phenol production industries, which makes the remediation process very difficult $[28,41,42]$. Considering these problems we practically checked the performance of amylase from $A$. gracilis TISTR 3638 with commercial grade amylase. Both amylases were able to increase the DO of the synthetic waste water. The results show that increasing salinity increased the performance of amylase from A. gracilis TISTR 3638, while it decreased the performance of commercial amylase. The use of halophilic enzymes has already been reported for the bioremediation of saline areas as well as for treatment of saline waste water $[43,44]$. As our enzyme has been found more salt loving than reported halophilic amylases, it provides the possibility of using it in saline and low water activity waste management. In addition to that the resilience of our reported amylase to inhibitors also makes it more potential candidate in waste water remediation processes as industrial effluents are often found to be contaminated with metallic ions as well.

\section{Conclusions}

The metabolites available from halophilic and obligate halophilic fungi have been much investigated. The polyextremophilic behavior of $\alpha$-amylase obtained from obligate halophilic A. gracilis TISTR 3638 provides the options of using it in industrial operations occurring in mild acidic and temperature conditions and at low water activity. The comparison of $\alpha$-amylase from this study with the commercial grade amylase for waste water remediation has shown that the amylase from A. gracilis TISTR 3638 can be applied for saline waste water remediation. There is still need for more in-depth studies to understand the biochemical behavior of $\alpha$-amylase from A. gracilis TISTR 3638.

\section{Conflict of Interests}

The authors declare that they have no conflict of interests.

\section{Acknowledgments}

The authors would like to thank all those who helped in their research. The research grant funds have been provided by agreement on Post-Doctoral Research Grant Allocation from the Ratchadaphisek Somphot Fund. This research has also been supported by National Research University Project, Office of Higher Education Commission (WCU-038-EN57).

\section{References}

[1] I. Ali, L. Kanhayuwa, S. Rachdawong et al., "Identification, phylogenetic analysis and characterization of obligate halophilic fungi isolated from a man-made solar saltern in Phetchaburi province, Thailand," Annals of Microbiology, vol. 63, no. 3, pp. 887-895, 2013.

[2] N. Gunde-Cimerman, J. C. Frisvad, P. Zalar et al., "Halotolerant and halophilic fungi," in Biodiversity of Fungi-Their Role in Human Life, S. K. Deshmukh and M. K. Rai, Eds., pp. 69-128, Oxford \& IBH, New Delhi, India, 2005.

[3] I. Ali, N. Siwarungson, H. Punnapayak et al., "Screening of potential biotechnological applications from obligate halophilic fungi, isolated from a man-made solar saltern located in Phetchaburi province, Thailand," Pakistan Journal of Botany, 2014.

[4] G. Antranikian, C. E. Vorgias, and C. Bertoldo, "Extreme environments as a resource for microorganisms and novel biocatalysts," Advances in Biochemical Engineering/Biotechnology, vol. 96, pp. 219-262, 2005.

[5] C. Gostinčar, M. Lenassi, N. Gunde-Cimerman, and A. Plemenitaš, "Fungal adaptation to extremely high salt concentrations," Advances in Applied Microbiology, vol. 77, pp. 71-96, 2011.

[6] S. DasSarma and P. DasSarma, Halophiles, Encyclopedia of Life Sciences, Wiley, London, UK, 2002.

[7] M. Delgado-García, B. Valdivia-Urdiales, C. N. AguilarGonzález et al., "Halophilic hydrolases as a new tool for the biotechnological industries," Journal of the Science of Food and Agriculture, vol. 92, no. 13, pp. 2575-2580, 2012.

[8] M. Moshfegh, A. R. Shahverdi, G. Zarrini et al., "Biochemical characterization of an extracellular polyextremophilic alphaamylase from the halophilic archaeon Halorubrum xinjiangense," Extremophiles, vol. 17, no. 4, pp. 677-687, 2013.

[9] M. E. Setati, "Diversity and industrial potential of hydrolaseproducing halophilic/halotolerant eubacteria," African Journal of Biotechnology, vol. 9, no. 11, pp. 1555-1560, 2010.

[10] H. Dalboge, "Expression cloning of fungal enzyme genes: a novel approach for efficient isolation of enzyme genes of industrial relevance," FEMS Microbiology Review, vol. 21, no. 1, pp. 29-42, 1997.

[11] X. D. Liu and Y. Xu, "A novel raw starch digesting $\alpha$-amylase from a newly isolated Bacillus sp. YX-1: purification and characterization," Bioresource Technology, vol. 99, no. 10, pp. 4315-4320, 2008.

[12] M. Shafiei, A. Ziaee, and M. A. Amoozegar, "Purification and biochemical characterization of a novel SDS and surfactant stable, raw starch digesting, and halophilic $\alpha$-amylase from a moderately halophilic bacterium, Nesterenkonia sp. strain F," Process Biochemistry, vol. 45, no. 5, pp. 694-699, 2010.

[13] K. K. Kiran and T. S. Chandra, "Production of surfactant and detergent-stable, halophilic, and alkalitolerant alpha-amylase by a moderately halophilic Bacillus sp. Strain TSCVKK," Applied Microbiology and Biotechnology, vol. 77, no. 5, pp. 1023-1031, 2008.

[14] M. S. Hernández, M. R. Rodríguez, N. P. Guerra, and R. P. Rosés, "Amylase production by Aspergillus niger in submerged cultivation on two wastes from food industries," Journal of Food Engineering, vol. 73, no. 1, pp. 93-100, 2006.

[15] S. Chakraborty, A. Khopade, C. Kokare, K. Mahadik, and B. Chopade, "Isolation and characterization of novel $\alpha$-amylase from marine Streptomyces sp. D1," Journal of Molecular Catalysis B: Enzymatic, vol. 58, no. 1-4, pp. 17-23, 2009. 
[16] N. Hmidet, A. Bayoudh, J. G. Berrin, S. Kanoun, N. Juge, and M. Nasri, "Purification and biochemical characterization of a novel $\alpha$-amylase from Bacillus licheniformis NH1. Cloning, nucleotide sequence and expression of amyN gene in Escherichia coli," Process Biochemistry, vol. 43, no. 5, pp. 499510, 2008.

[17] G. L. Miller, "Use of dinitrosalicylic acid reagent for determination of reducing sugar," Analytical Chemistry, vol. 31, no. 3, pp. 426-428, 1959.

[18] O. H. Lowry, N. J. Rosebrough, A. L. Farr, and R. J. Randall, "Protein measurement with the Folin phenol reagent," The Journal of Biological Chemistry, vol. 193, no. 1, pp. 265-275, 1951.

[19] I. K. Kapdan and B. Erten, "Anaerobic treatment of saline wastewater by Halanaerobium lacusrosei," Process Biochemistry, vol. 42, no. 3, pp. 449-453, 2007.

[20] P. M. de Souza and P. O. Magalhães, "Application of microbial $\alpha$ amylase in industry-a review," Brazilian Journal of Microbiology, vol. 41, no. 4, pp. 850-861, 2010.

[21] R. Gupta, P. Gigras, H. Mohapatra, V. K. Goswami, and B. Chauhan, "Microbial $\alpha$-amylases: a biotechnological perspective," Process Biochemistry, vol. 38, no. 11, pp. 1599-1616, 2003.

[22] K. Kathiresan and S. Manivannan, " $\alpha$-Amylase production by Penicillium fellutanum isolated from mangrove rhizosphere soil," African Journal of Biotechnology, vol. 5, no. 10, pp. 829-832, 2006.

[23] F. Niknejad, M. Moshfegh, M. J. Najafzadeh et al., "Halotolerant ability and $\alpha$-amylase activity of some saltwater fungal isolates," Iranian Journal of Pharmaceutical Research, vol. 12, pp. 113-119, 2013.

[24] R. Kammoun, B. Naili, and S. Bejar, "Application of a statistical design to the optimization of parameters and culture medium for $\alpha$-amylase production by Aspergillus oryzae CBS 819.72 grown on gruel (wheat grinding by-product)," Bioresource Technology, vol. 99, no. 13, pp. 5602-5609, 2008.

[25] M. F. Najafi and A. Kembhavi, "One step purification and characterization of an extracellular $\alpha$-amylase from marine Vibrio sp.," Enzyme and Microbial Technology, vol. 36, no. 4, pp. 535-539, 2005.

[26] A. Asoodeh, J. Chamani, and M. Lagzian, "A novel thermostable, acidophilic $\alpha$-amylase from a new thermophilic "Bacillus sp. Ferdowsicous" isolated from Ferdows hot mineral spring in Iran: purification and biochemical characterization," International Journal of Biological Macromolecules, vol. 46, no. 3, pp. 289-297, 2010.

[27] J. Matzke, B. Schwermann, and E. P. Bakker, "Acidostable and acidophilic proteins: the example of the alpha-amylase from Alicyclobacillus acidocaldarius," Comparative Biochemistry and Physiology A, vol. 118, no. 3, pp. 475-479, 1997.

[28] M. Al-Harahsheh, M. Batiha, S. Kraishan, and H. Al-Zoubi, "Precipitation treatment of effluent acidic wastewater from phosphate-containing fertilizer industry: characterization of solid and liquid products," Separation and Purification Technology, vol. 123, pp. 190-199, 2014.

[29] O. Prakash and N. Jaiswal, “ $\alpha$-Amylase: an ideal representative of thermostable enzymes," Applied Biochemistry and Biotechnology, vol. 160, no. 8, pp. 2401-2414, 2010.

[30] S. A. Fincan and B. Enez, "Production, purification, and characterization of thermostable $\alpha$-amylase from thermophilic Geobacillus stearothermophilus," Starch-Stärke, vol. 66, no. 1-2, pp. 182-189, 2014.

[31] I. Gomes, J. Gomes, and W. Steiner, "Highly thermostable amylase and pullulanase of the extreme thermophilic eubacterium
Rhodothermus marinus: production and partial characterization," Bioresource Technology, vol. 90, no. 2, pp. 207-214, 2003.

[32] M. A. Amoozegar, F. Malekzadeh, and K. A. Malik, "Production of amylase by newly isolated moderate halophile, Halobacillus sp. strain MA-2," Journal of Microbiological Methods, vol. 52, no. 3, pp. 353-359, 2003.

[33] M. Shafiei, A. Ziaee, and M. A. Amoozegar, "Purification and characterization of a halophilic a-amylase with increased activity in the presence of organic solvents from the moderately halophilic Nesterenkonia sp. strain F," Extremophiles, vol. 16, no. 4, pp. 627-635, 2012.

[34] W. Asad, M. Asif, and S. A. Rasool, "Extracellular enzyme production by indigenous thermophilic bacteria: partial purification and characterization of $\alpha$-amylase by Bacillus sp. WA21," Pakistan Journal of Botany, vol. 43, no. 2, pp. 1045-1052, 2011.

[35] S. Ghizellaoui, A. Chibani, and S. Ghizellaoui, "Use of nanofiltration for partial softening of very hard water," Desalination, vol. 179, no. 1-3, pp. 315-322, 2005.

[36] J. Morrison, M. Morikawa, M. Murphy et al., "Water Scarcity \& Climate Change: Growing Risks for Businesses \& Investors. Pacific Institute," 2009, http://www.pacinst.org/reports/business_water_climate/full_report.pdf.

[37] J. S. Park, J. H. Song, K. H. Yeon, and S. Moon, "Removal of hardness ions from tap water using electromembrane processes," Desalination, vol. 202, no. 1-3, pp. 1-8, 2007.

[38] T. S. Zhang, S. Datta, J. Eichler et al., "Identification of a haloalkaliphilic and thermostable cellulase with improved ionic liquid tolerance," Green Chemistry, vol. 13, no. 8, pp. 2083-2090, 2011.

[39] M. C. Cammarota and D. M. G. Freire, "A review on hydrolytic enzymes in the treatment of wastewater with high oil and grease content," Bioresource Technology, vol. 97, no. 17, pp. 2195-2210, 2006.

[40] Z. Guizhong, L. Jia, F. Huiju, S. Jing, and Z. Xiaoqing, "Starch wastewater treatment with effective microorganisms bacteria," in Proceedings of the 4th International Conference on Bioinformatics and Biomedical Engineering (iCBBE '10), vol. 1, pp. 18-20, Chengdu, China, June 2010.

[41] N. P. Dan, C. Visvanathan, and B. Basu, "Comparative evaluation of yeast and bacterial treatment of high salinity wastewater based on biokinetic coefficients," Bioresource Technology, vol. 87, no. 1, pp. 51-56, 2003.

[42] M. H. Zhou, Z. C. Wu, and D. H. Wang, "Electrocatalytic degradation of phenol in acidic and saline wastewater," Journal of Environmental Science and Health, vol. 37, no. 7, pp. 1263-1275, 2002.

[43] J. Chung, S. Shin, and J. Oh, "Characterization of a microbial community capable of reducing perchlorate and nitrate in high salinity," Biotechnology Letters, vol. 31, no. 7, pp. 959-966, 2009.

[44] R. Margesin and F. Schinner, "Biodegradation and bioremediation of hydrocarbons in extreme environments," Applied Microbiology and Biotechnology, vol. 56, no. 5-6, pp. 650-663, 2001. 

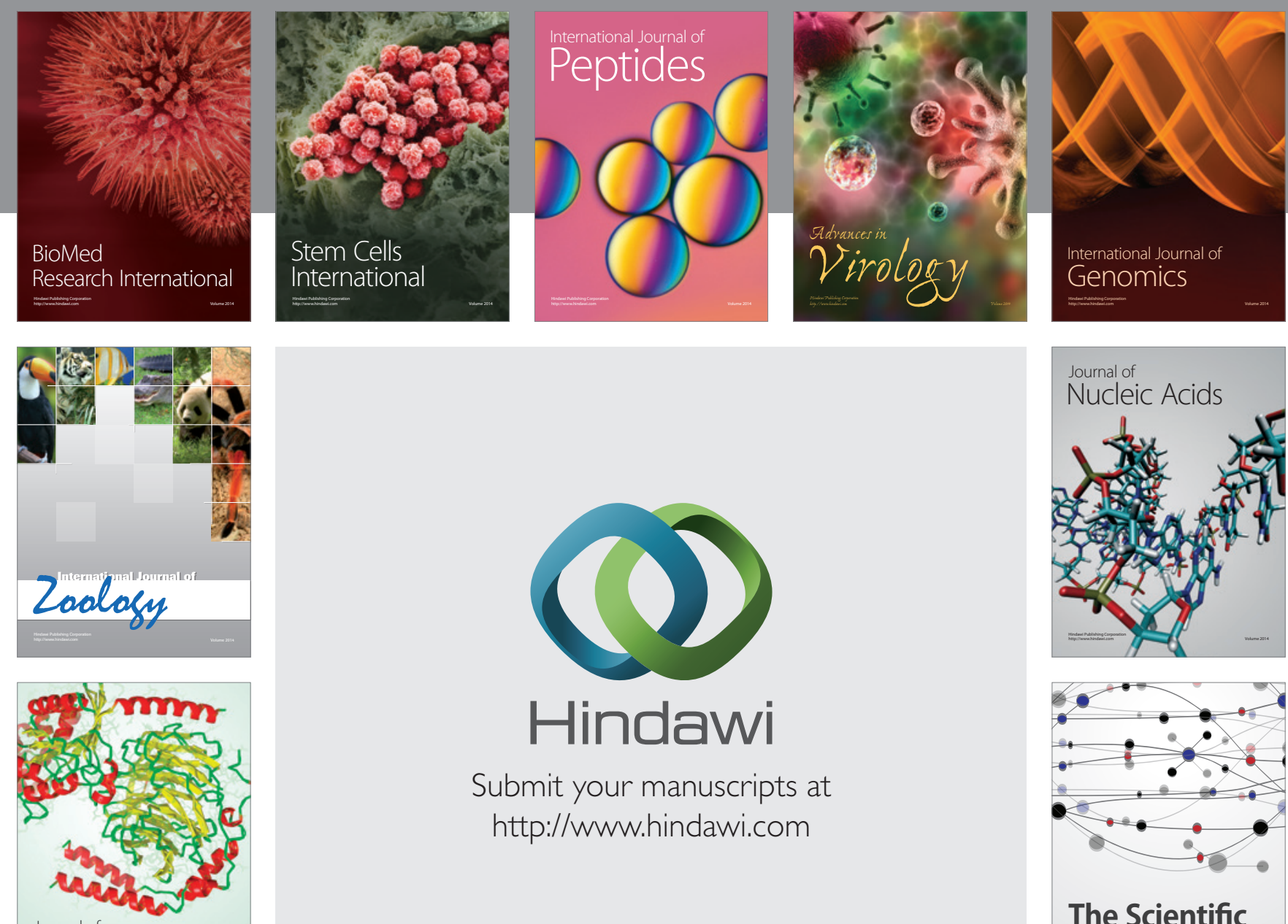

Submit your manuscripts at

http://www.hindawi.com

Journal of
Signal Transduction
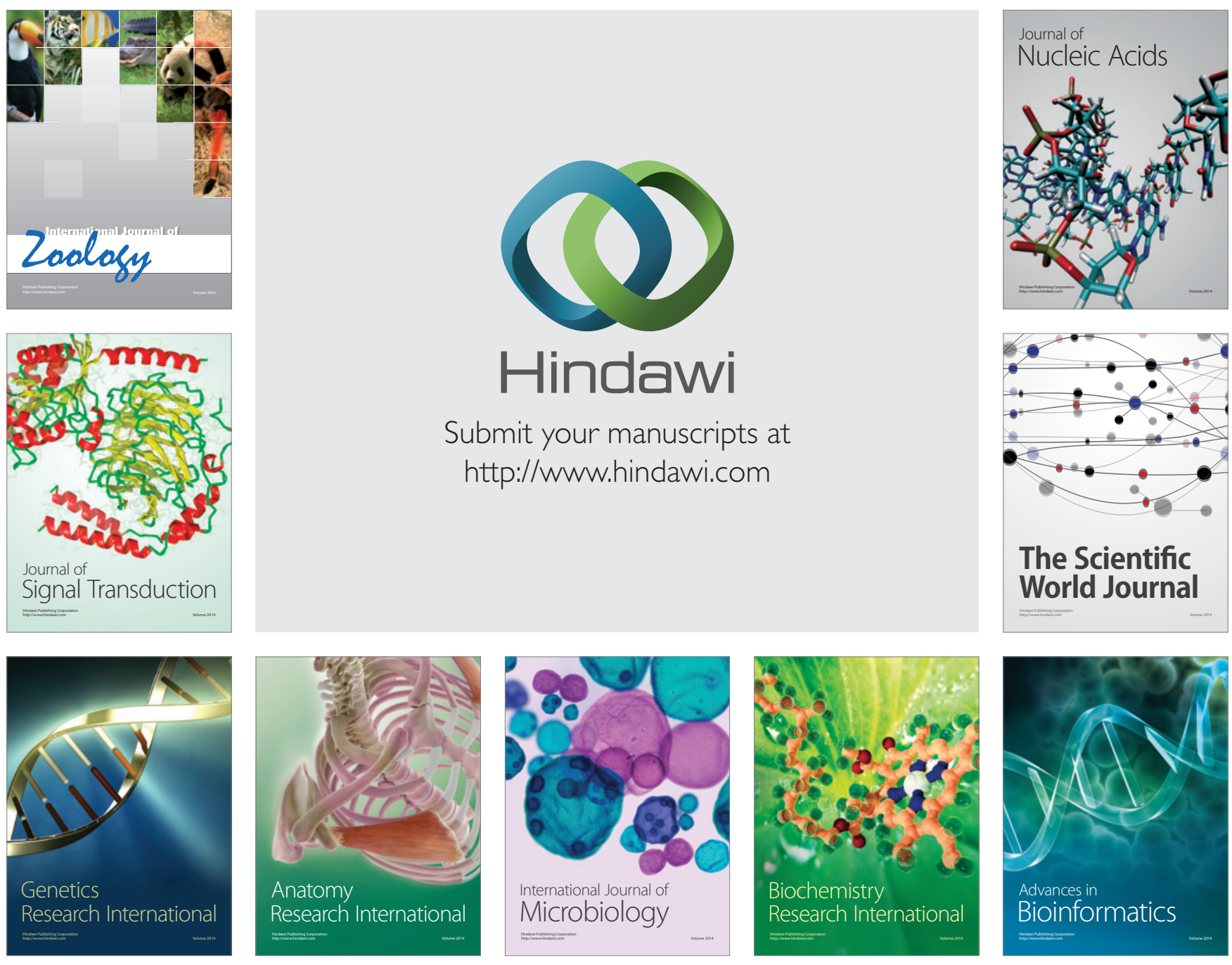

The Scientific World Journal
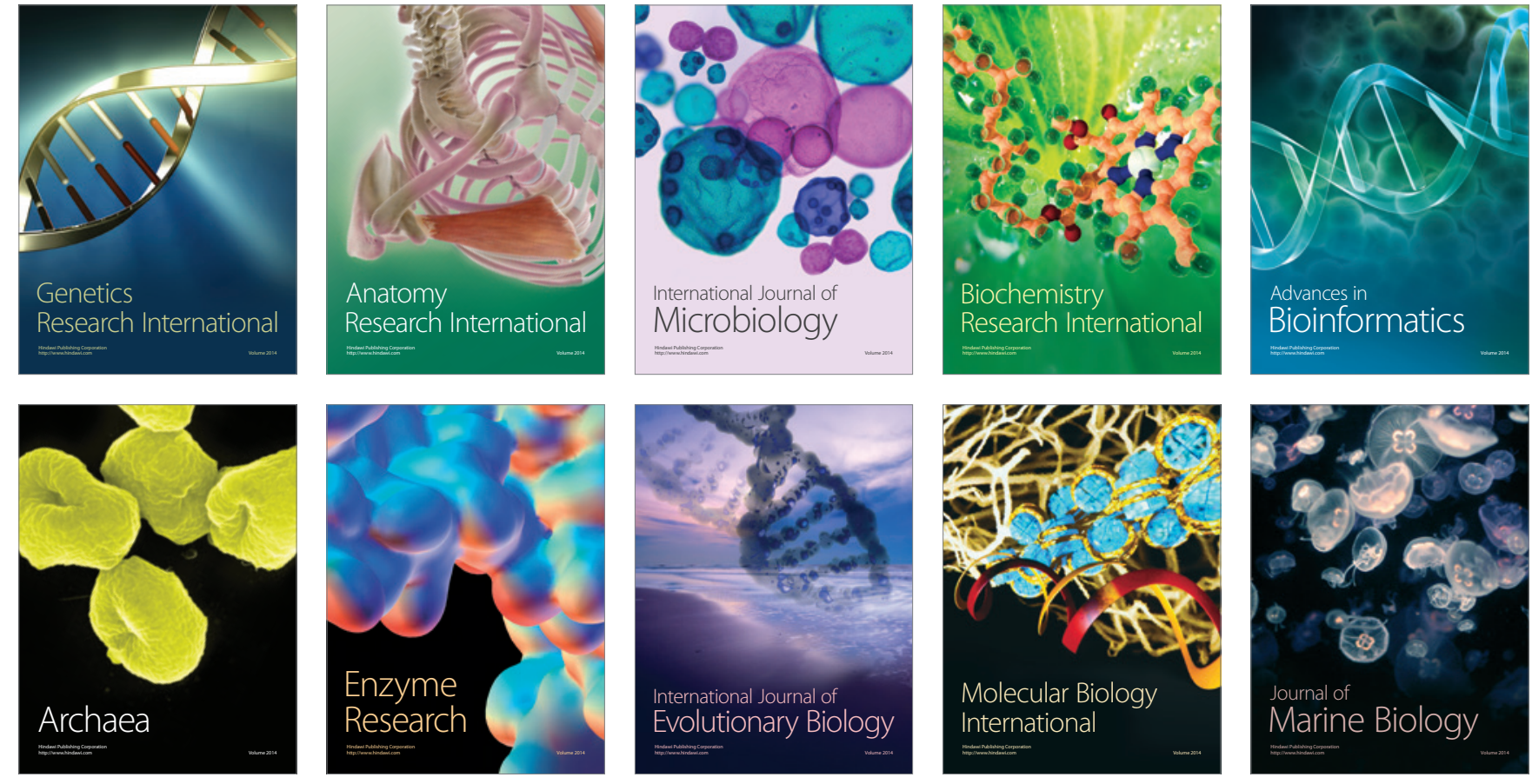